\title{
Correction: Disease duration, age at diagnosis and organ damage are important factors for cardiovascular disease in SLE
}

Nived O, Ingvarsson RF, Jöud A, et al. Disease duration, age at diagnosis and organ damage are important factors for cardiovascular disease in SLE. Lupus Sci Med 2020;7:e000398. doi: 10.1136/lupus-2020-000398

The article has been corrected since it was published online. In the published version, the co-authors' names were misspelled as Ragnar Frey Ingvarsson and Helena Tyden. The correct names have been amended as Ragnar Freyr Ingvarsson and Helena Tydén.

\section{(2) \\ OPEN ACCESS}

Open access This is an open access article distributed in accordance with the Creative Commons Attribution 4.0 Unported (CC BY 4.0) license, which permits others to copy, redistribute, remix, transform and build upon this work for any purpose, provided the original work is properly cited, a link to the licence is given, and indication of whether changes were made. See: https://creativecommons.org/licenses/by/4.0/.

Lupus Sci Med 2020;7:e000398corr1. doi:10.1136/lupus-2020-000398corr1

D) Check for updates 